\begin{tabular}{ll}
\hline \hline MINING AND METALLURGY INSTITUTE BOR & ISSN: 2334-8836 (Štampano izdanje) \\
UDK: 622 & ISSN: 2406-1395 (Online) \\
\hline \hline
\end{tabular}

\title{
ANALYSIS OF COAL QUALITY IN A FUNCTION OF SELECTION LEVEL FOR MINING AT THE OPEN PIT GACKO****
}

\section{Abstract}

This work analyzes the quality of coal in the function level selection for exploitation. A detailed analysis was carried out for the main coal seam, the first floor seam, the second floor seam and the overlying coal series of the coal deposit Gacko of 0.5 and $1 \mathrm{~m}$. The analysis was carried out within the Strategy of mining-technological opening, development, optimization and maintenance the continuity of coal production with development the Feasibility Study of introducing a dry separation method in order to determine the amount and quality of coal for TPP Gacko. The analysis included the effects of natural and technological factors on participation the seam overburden in the run-of-mine coal as well as a degree of overburden impact on the quality of run-of-mine coal.

Keywords: selective mining, coal quality, TPP, Gacko

\section{INTRODUCTION}

The open pit coal mining represents a large installed capacities for the needs of energetics and is characterized by a very extensive and complex production complexes within the exploitation system.

Coal deposits, predisposed for the open pit mining, are frequently characterized by a complex structure and operating conditions. Further development of the open pit mining is also related to more complex engineering-geological, and hydrogeological characteristics of the working environment, the increased overburden coefficient, more demanding environmental conditions, which all together emphasizes a need for use the modern technological mining methods, and even selective mining that becomes more and more pronounced.

Selective coal mining in these circumstances gets more importance from the standpoint of efficiency of reserves in the deposit, and in some cases is imposed as the only possibility of mining. It is often the case that the use of selective mining allows the evaluation of those coal reserves that otherwise could not be balanced as an energy source.

In any case, whether it is a mass or selective mining, the coal excavation is carried out in a particular work environment that represents the environment of production system, with a group of specific chara-

\footnotetext{
* Mining and Metallurgy Institute Bor - Department Coal Engineering Belgrade e-mail: sasa.stepanovic@irmbor.co.rs

*** Mine and Power Plant Gacko, e-mail: miodrag.seslija@ ritegacko-rs.ba

*** This work is derived from the project TR37001 "The Impact of Mining Waste from RTB Bor on the Pollution of Surrounding Water Systems with the Proposal of Measures and Procedures for Reduction Harmful Effect on the Environment", funded by the Ministry of Education, Science and Technological Development of the Republic of Serbia
} 
cteristics that affect the choice of parameters for operation technology.

\section{SELECTIVE COAL MINING AT THE OPEN PIT GACKO}

Coal mining in the Gacko coal basin is carried out using the technology of selective coal mining. Orientation to the selective mining has been demonstrated in terms of efficiency and valorization the available coal reserves, then from the viewpoint of the needs and possibilities of coal homoge- nization, and also as the only method of coal mining with an extremely complex structure of coal bearing series.

The coal deposit Centralno Polje is more predisposed to the open pit mining, and is characterized by complex mining conditions, from the aspect of geological structure of coal bearing seams.

Within this exploration-exploitation field of the Gacko coal basin, three coal seams have been developed within the roof coal series, then the main, the first and the second floor coal seam (Figure 1).

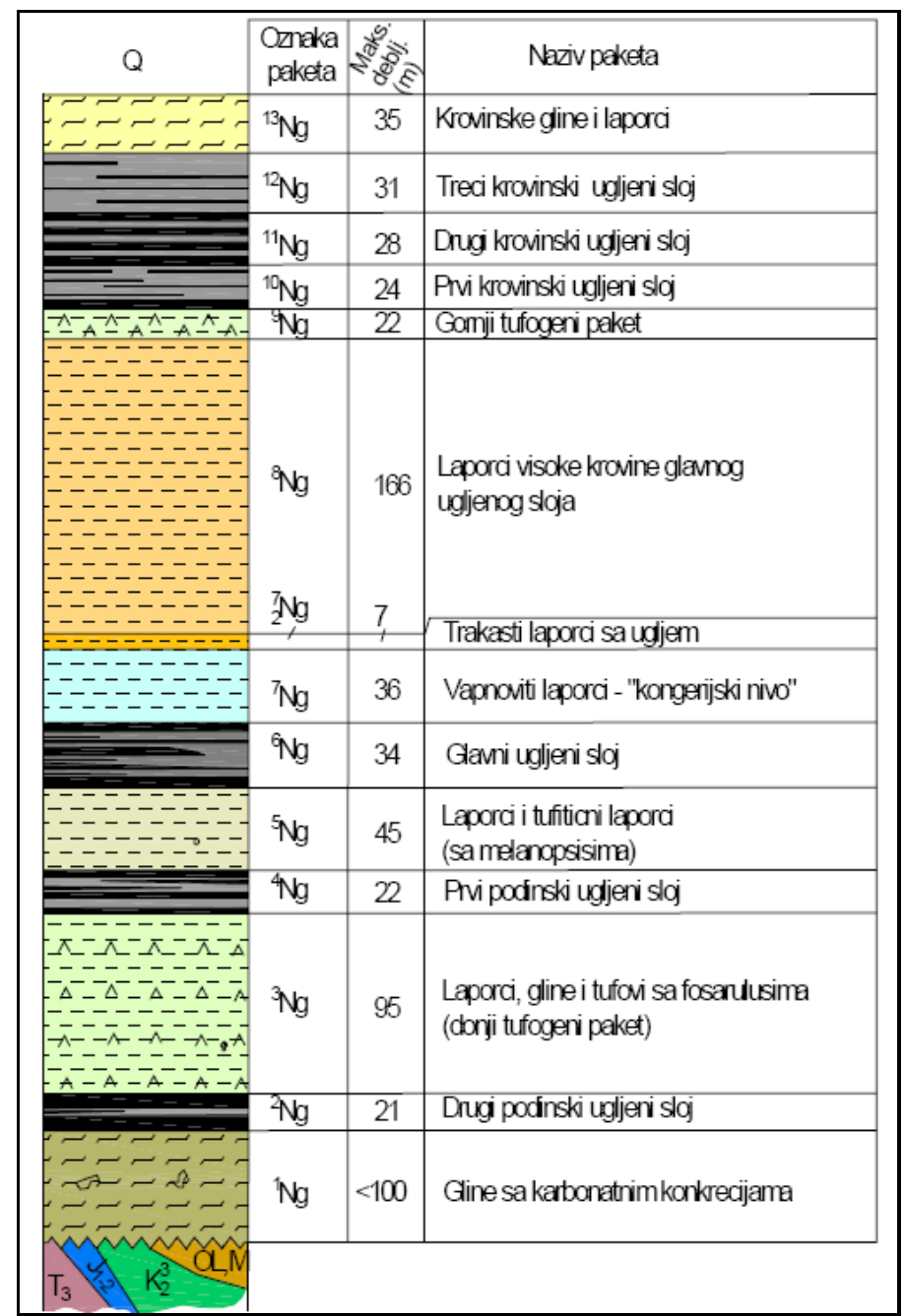

Figure 1 Lithostratigraphic pillar of the Neogene series of the Gacko coal basin 
All coal seams are complex or stratified with greater or lesser presence of waste thin seam.

Coal, mined in this deposit, is intended to supply the thermo power plant, and the major limitation in terms of exploitability is the quality of run-of-mine coal. In the mining dynamics defining, the quality of runoff-mine coal was analyzed in the specific mining conditions. In addition to the other factors, a dilution of mineral raw material was observed as the result of the coal seam structure. Dilution occurs in mining a certain amount of waste from a contact of coal seam or thin seam.

This causes a reduction in calorific value compared to the coal calorific value determined during the deposit exploration. In a coal supply to the thermal power plants, as a condition, there is exactly a certain minimum calorific value that is a limit for the percentage presence of waste material in coal, that is, the level or degree of dilution, in this particular case the followings are analuzed, such as: the roof, the main, the first and the second floor coal seam.

Coal dilution is determined for the selection level during excavation of 0.5 and $1 \mathrm{~m}$.

The selection level is minimum thickness of thin seams or a group of thin seams which are mined as the run-of-mine coal. Thins seams of coal are mined as the run-of-mine coal in two cases, as follows:

1. if their thickness is greater than the selection level, and

2. if their thickness is less than the selection level wherein the thickness of waste thin seam between two adjacent coal thin seams is less, and the sum of thicknesses of adjacent coal thin seams is greater than the selection level.
The same is also applied to the waste thin seams which are mined as the selective waste material.

If the coal thickness is less than the selection level in mining, the losses occur, while if the waste thickness is less than the selection level, a dilution occurs.

The analysis of dilution in a function of stratigraphic position interlayers of coal thin seams within the coal seams was carried out such as the pillars of drill holes were analyzed, and the presence of coal and waste thin seams of thickness less than the selected level, and their mutual position. The basis for the analysis was the basis of exploration work results (exploratory drill holes) from which the waste thin seams were firstly identified that are mined together with coal, followed by the calculation the total amount of run-of-mine coal and degree of presence the waste in the total weight of coal. Data regarding the percentage of dilution are connected to the corresponding coal seam and corresponding exploration work, and the analyzed data had its coordinates in a real space. Subsequent interpretation was carried out using a suitable software package, and the results are shown in a form of isolines of dilution percentage. In addition to the presented spatial arrangement and percentage of volume dilution, was performed and the statistical analysis of this data was performed, and the appropriate measures of tendency and dispersion were given. Further text presents the analysis results for the selection level of 0.5 and $1 \mathrm{~m}$.

\section{DILUTION FOR THE SELECTION LEVEL OF 0.5 m}

Isolines of coal dilution in $\%$ by volume participation in the coal seam for the roof, main, first and second floor seam are given in Figures 2 to 5. 


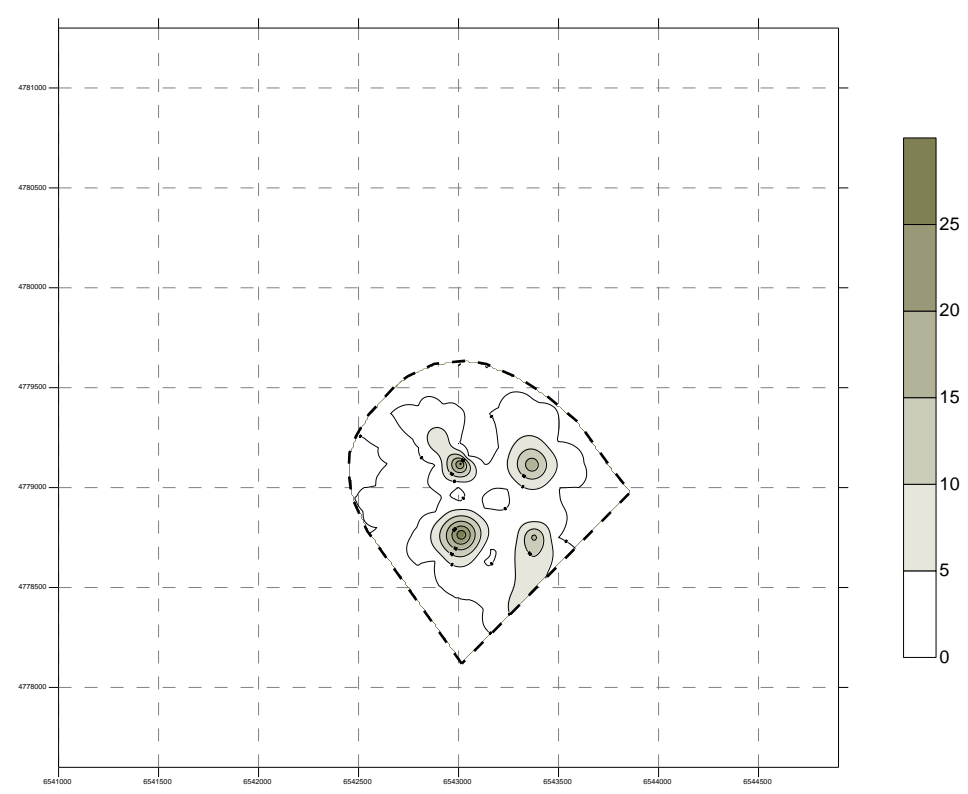

Figure 2 Isolines of coal dilution percentage in the roof coal seam for the selection level $0.5 \mathrm{~m}$

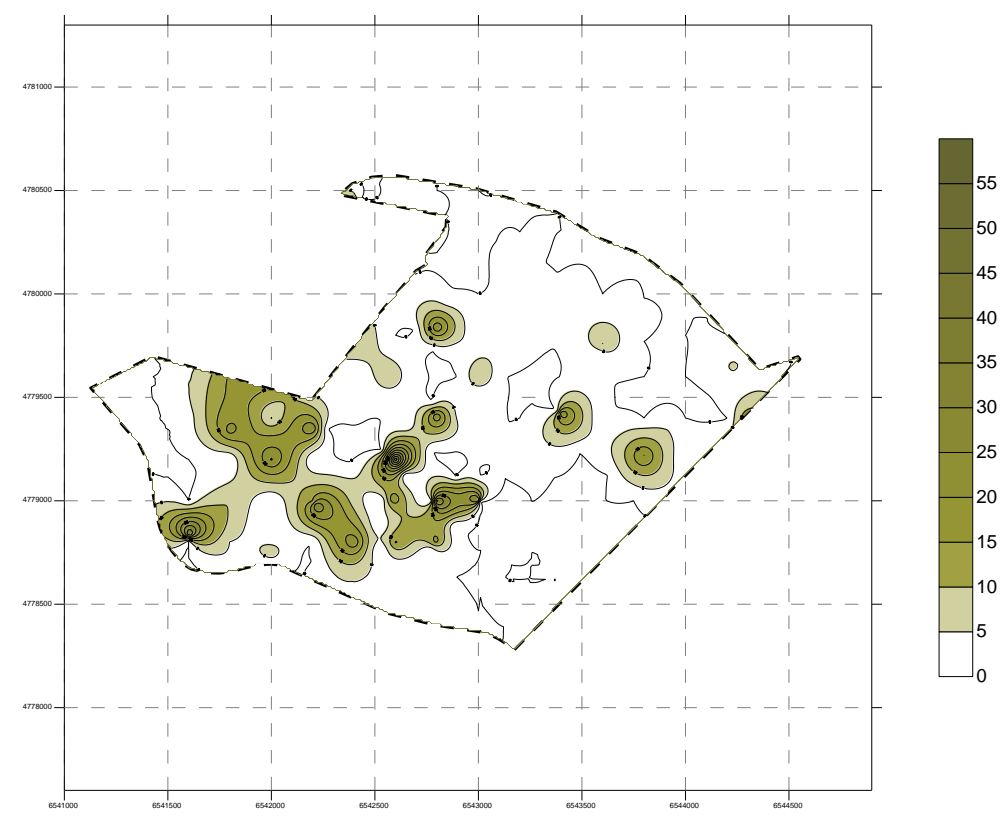

Figure 3 Isolines of coal dilution percentage in the main coal seam for the selection level $0.5 \mathrm{~m}$ 


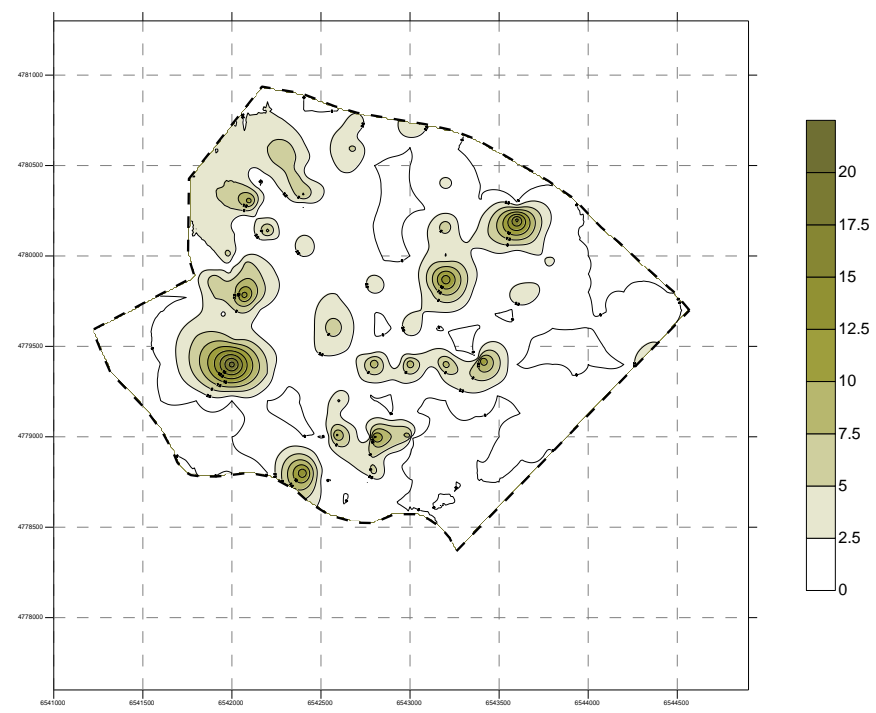

Figure 4 Isolines of coal dilution percentage in the first floor coal seam for the selection level $0.5 \mathrm{~m}$

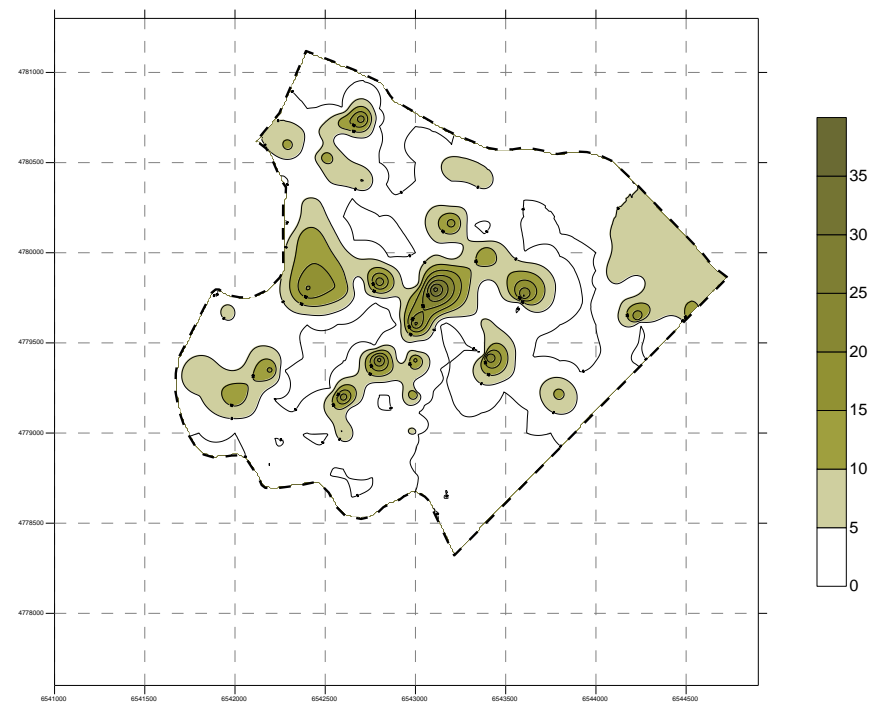

Figure 5 Isolines of coal dilution percentage in the second floor coal seam for the selection level $0.5 \mathrm{~m}$

Histograms of dilution percentage by the coal seams are given in Figure 6. 


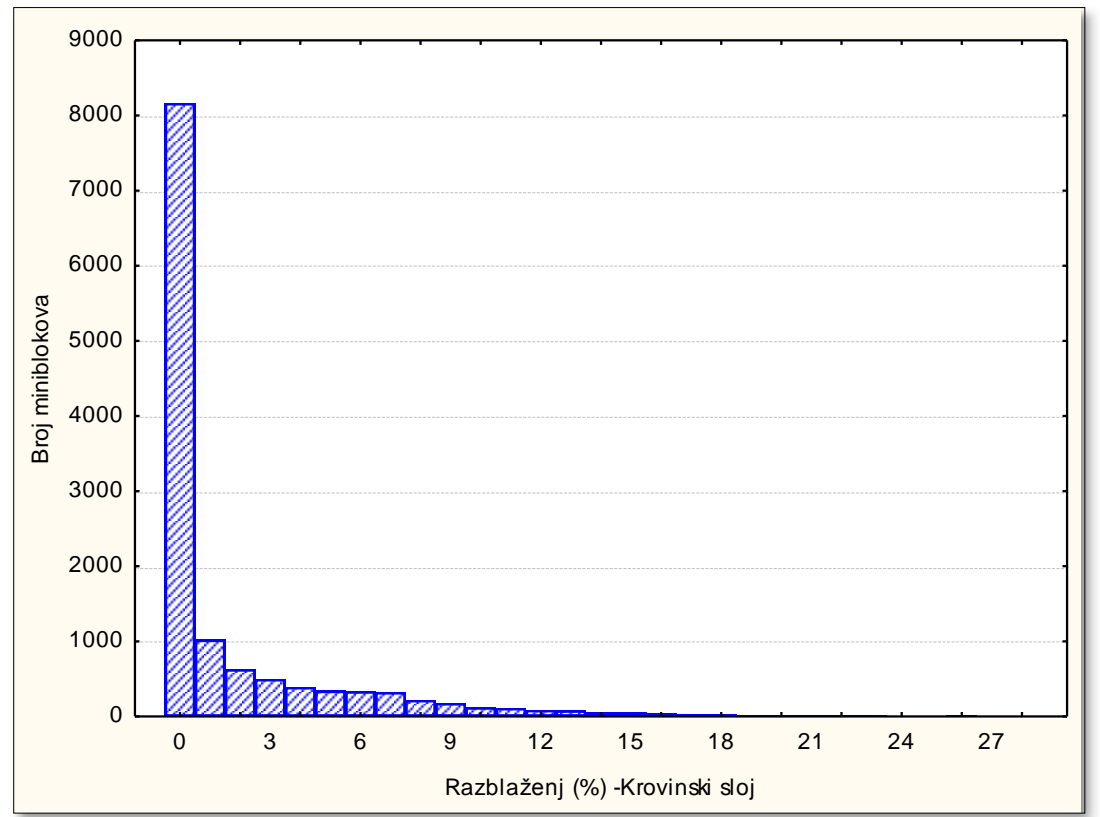

a)

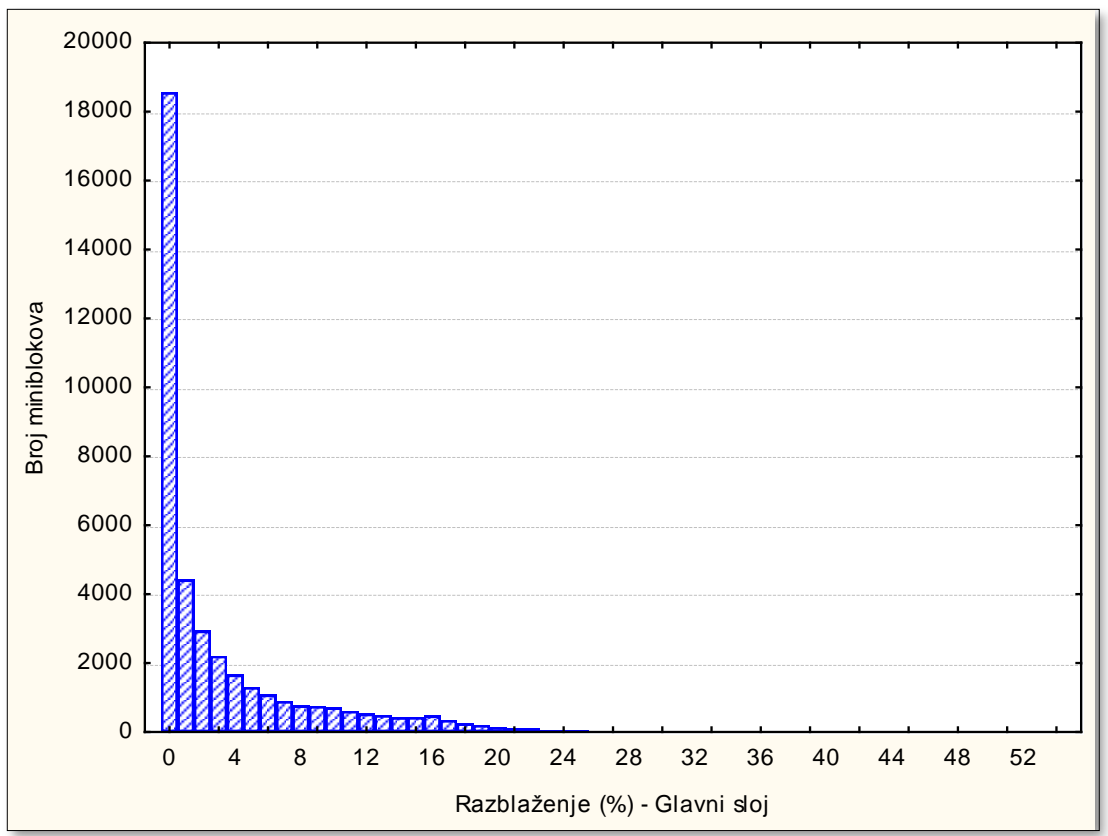

b) 


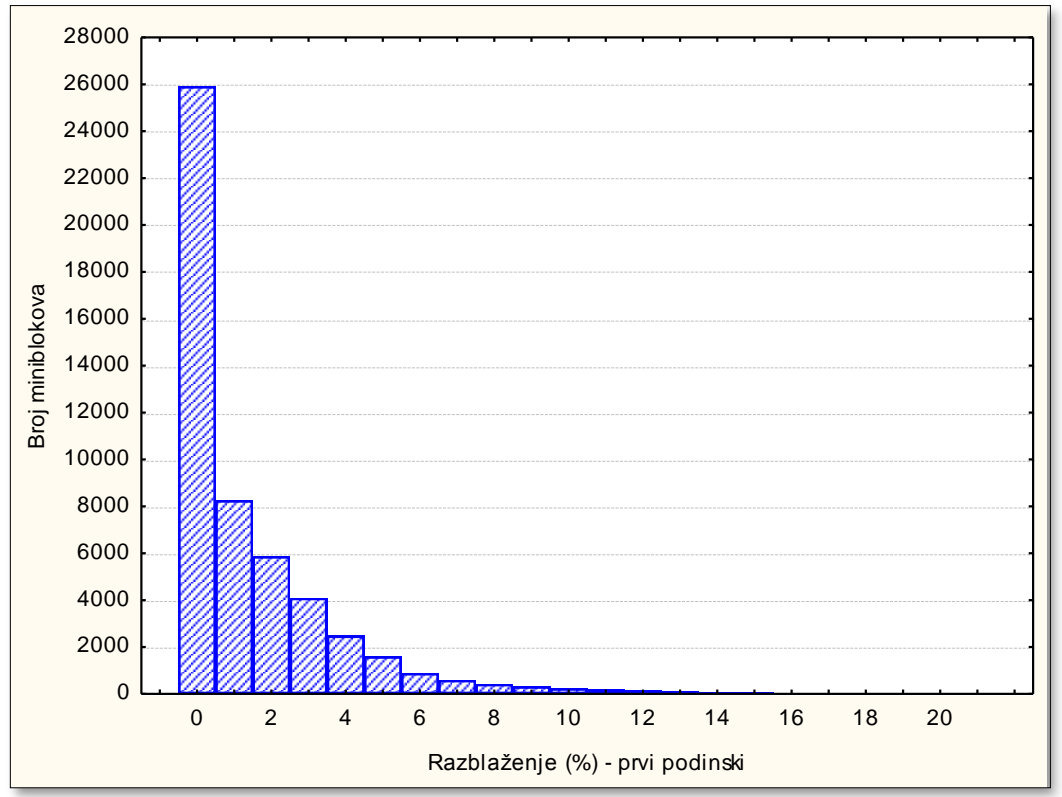

c)

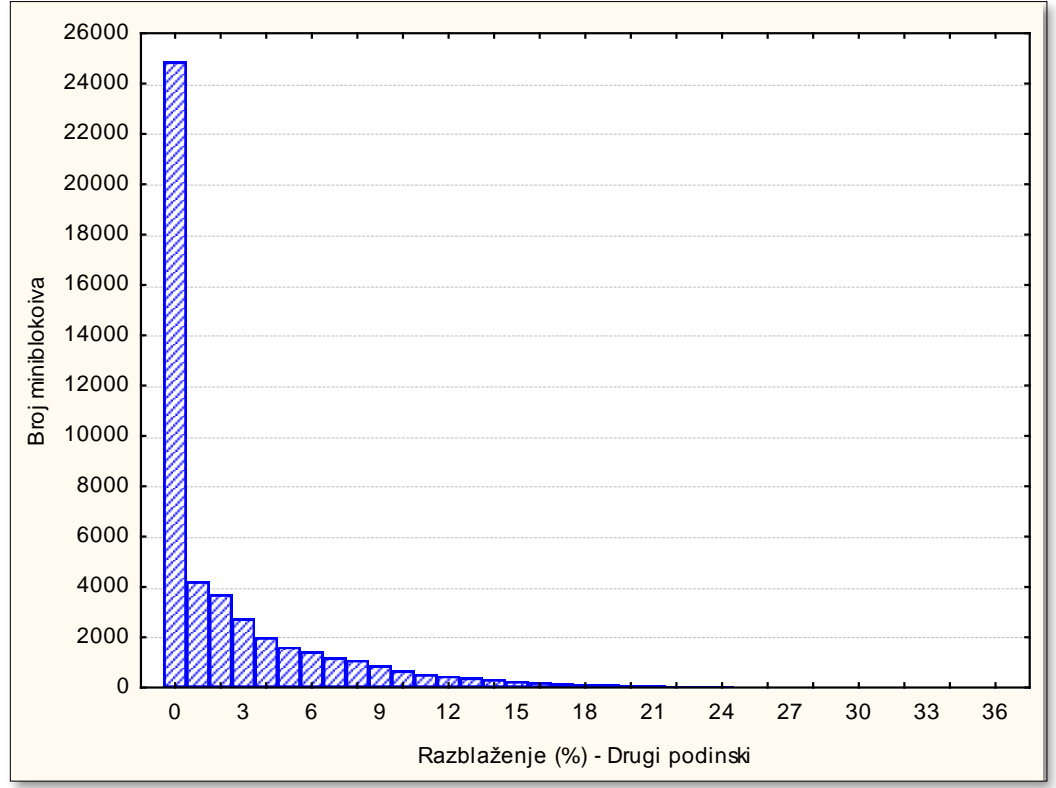

d)

Figure 6 Histograms of the dilution percentage by coal seams (a-roof, b-main, $c$-first floor and d-second floor coal seam) for the level selection of $0.5 \mathrm{~m}$ 
Table 1 Results of statistical analysis of dilution at the selection level of $0.5 \mathrm{~m}$

\begin{tabular}{|l|c|c|c|c|}
\hline \multicolumn{1}{|c|}{ Characteristic } & $\begin{array}{c}\text { Roof coal } \\
\text { seam }\end{array}$ & $\begin{array}{c}\text { Main coal } \\
\text { seam }\end{array}$ & $\begin{array}{c}\text { Second floor } \\
\text { coal seam }\end{array}$ & $\begin{array}{c}\text { First floor } \\
\text { coal seam }\end{array}$ \\
\hline Arithmetic mean & 2.144 & 3.672 & 1.823 & 2.837 \\
\hline Median & 0.069 & 1.227 & 0.969 & 0.773 \\
\hline Standard deviation & 3.883 & 5.418 & 2.405 & 4.345 \\
\hline Number of miniblocks & 12779 & 39661 & 51173 & 47227 \\
\hline Minimum & 0.000 & 0.000 & 0.000 & 0.000 \\
\hline Maximum & 28.605 & 54.048 & 21.739 & 36.939 \\
\hline I quartile & 0.000 & 0.000 & 0.048 & 0.000 \\
\hline II quartile & 2.595 & 4.982 & 2.674 & 3.962 \\
\hline
\end{tabular}

\section{DILUTION FOR THE SELECTION}

\section{LEVEL OF 1 m}

Isolines of coal dilution in $\%$ by vol- roof, main, first and second floor seam are ume participation in the coal seam for the given in Figures 7 to 10.

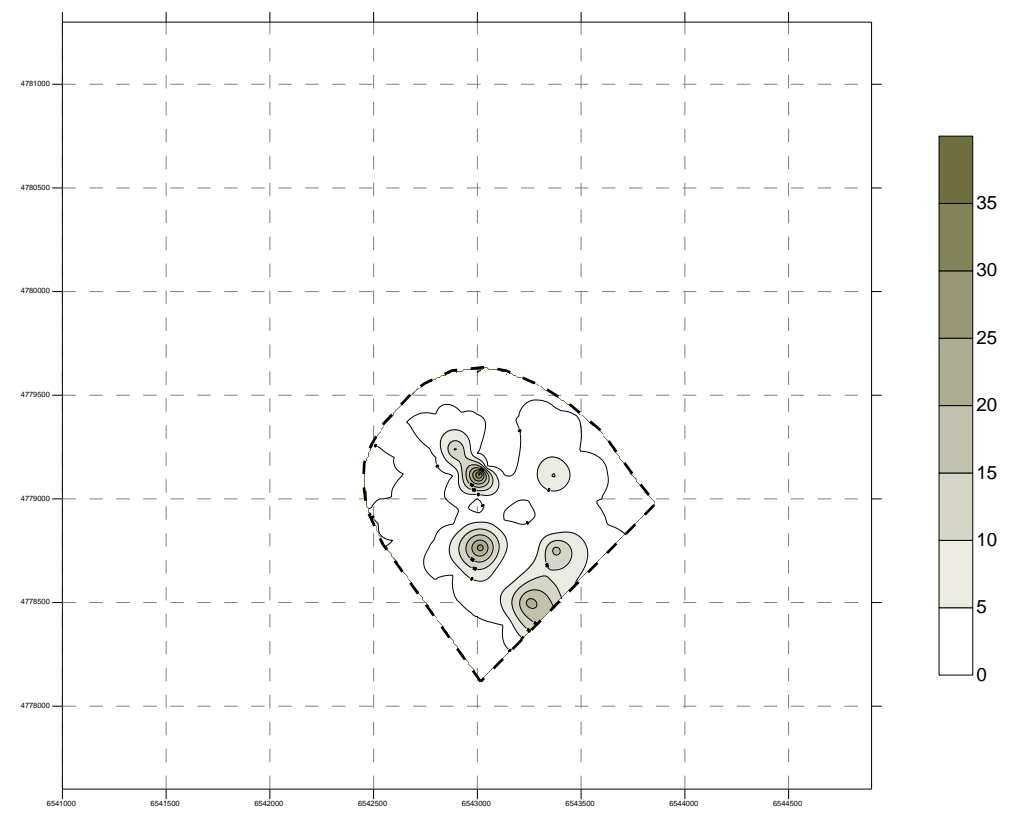

Figure 7 Isolines of coal dilution percentage in the roof coal seam for the selection level $1 \mathrm{~m}$ 


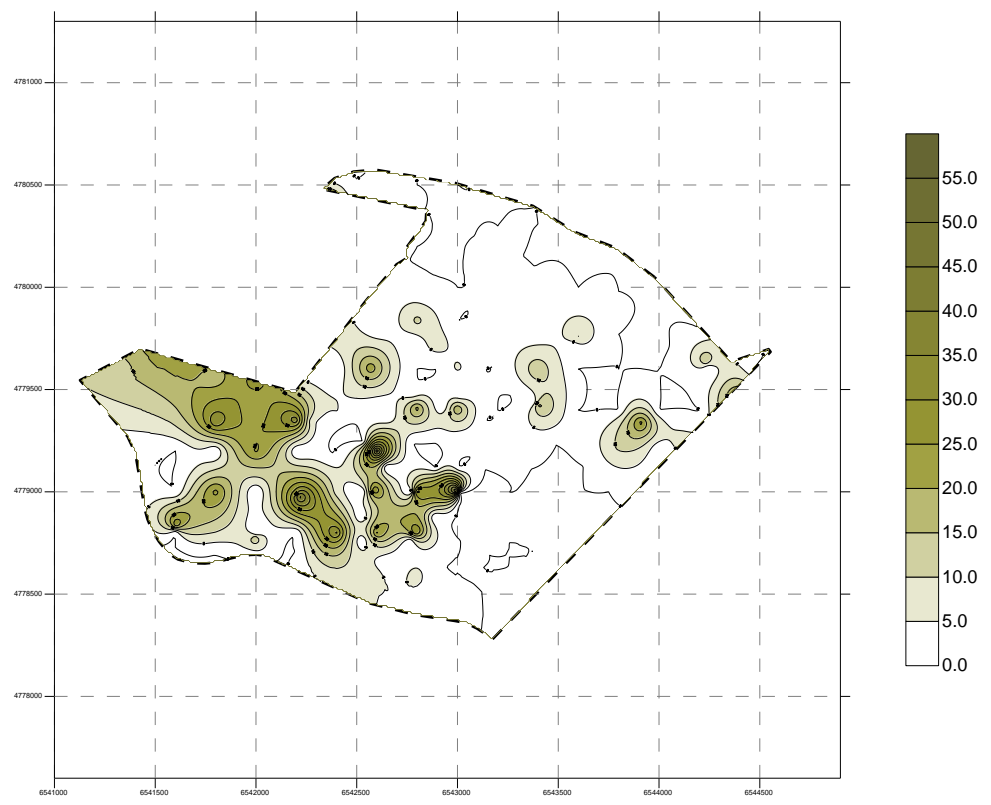

Figure 8 Isolines of coal dilution percentage in the main coal seam for the selection level $1 \mathrm{~m}$

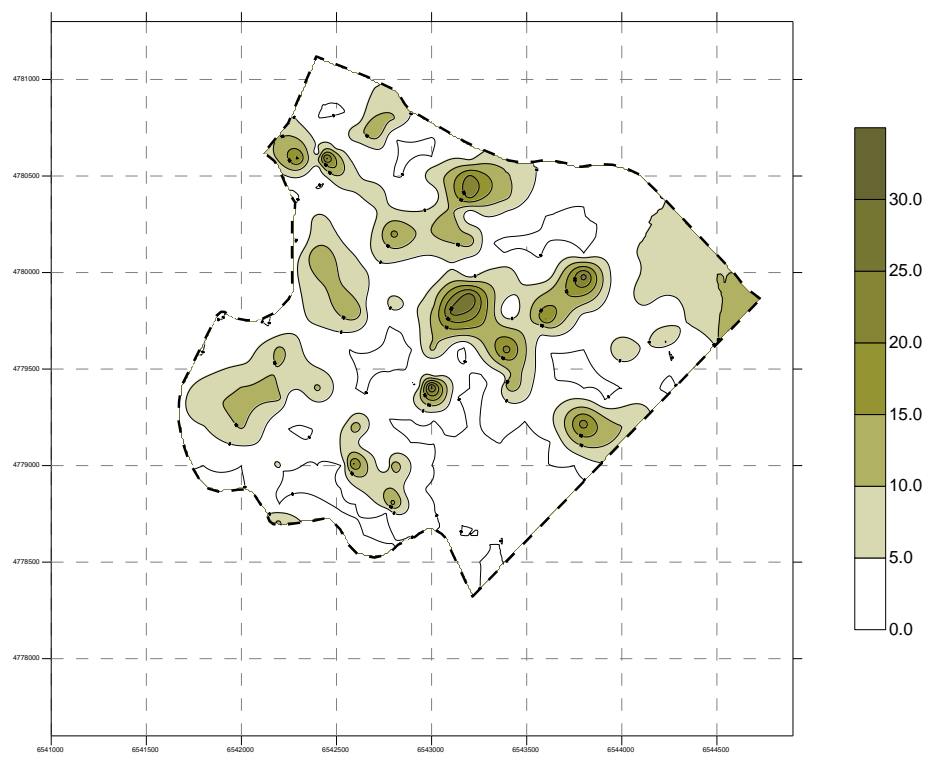

Figure 9 Isolines of coal dilution percentage in the first floor coal seam for the selection level $1 \mathrm{~m}$ 


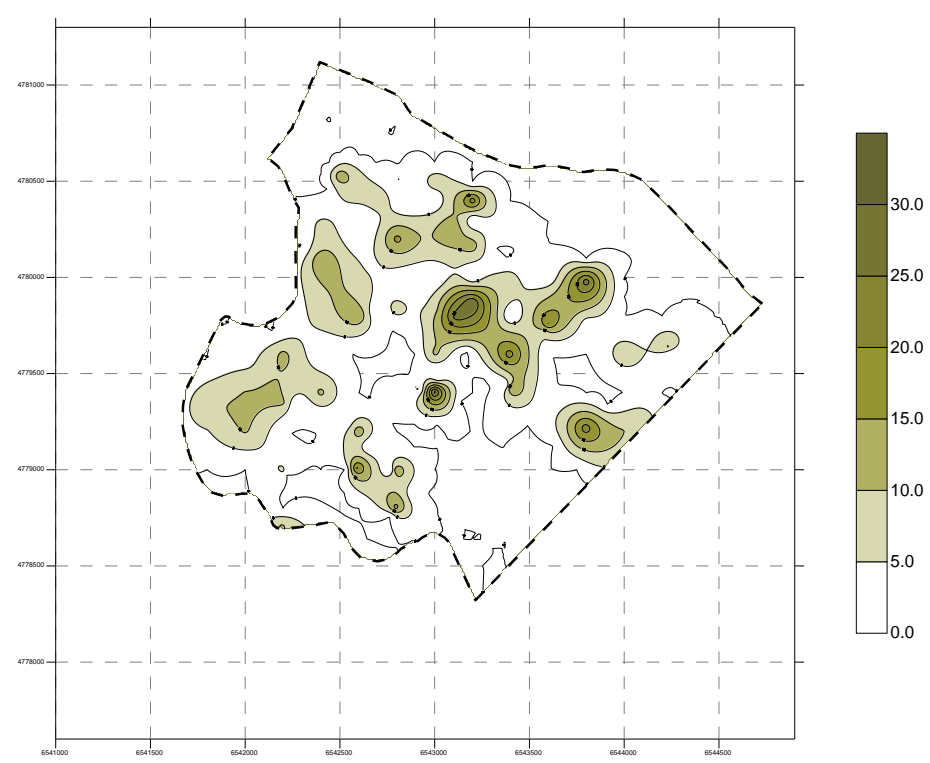

Figure 10 Isolines of coal dilution percentage in the second floor coal seam for the selection level $1 \mathrm{~m}$

Histograms of dilution percentage by the coal seams are given in Figure 11.

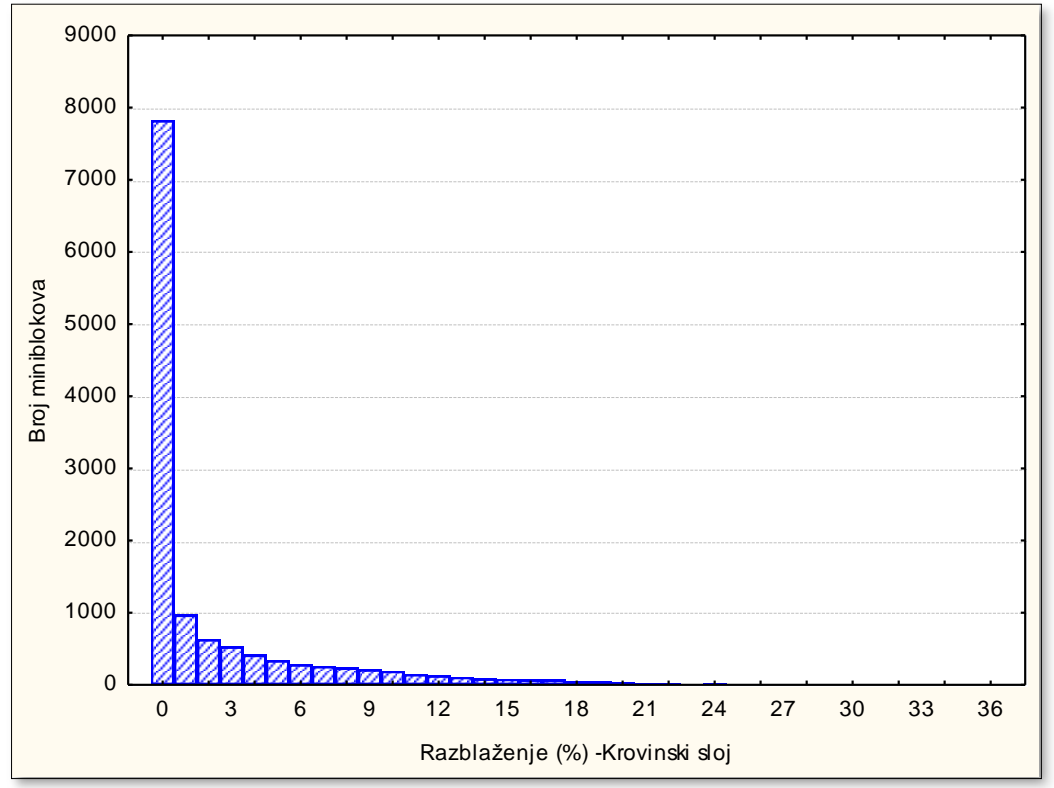

a) 


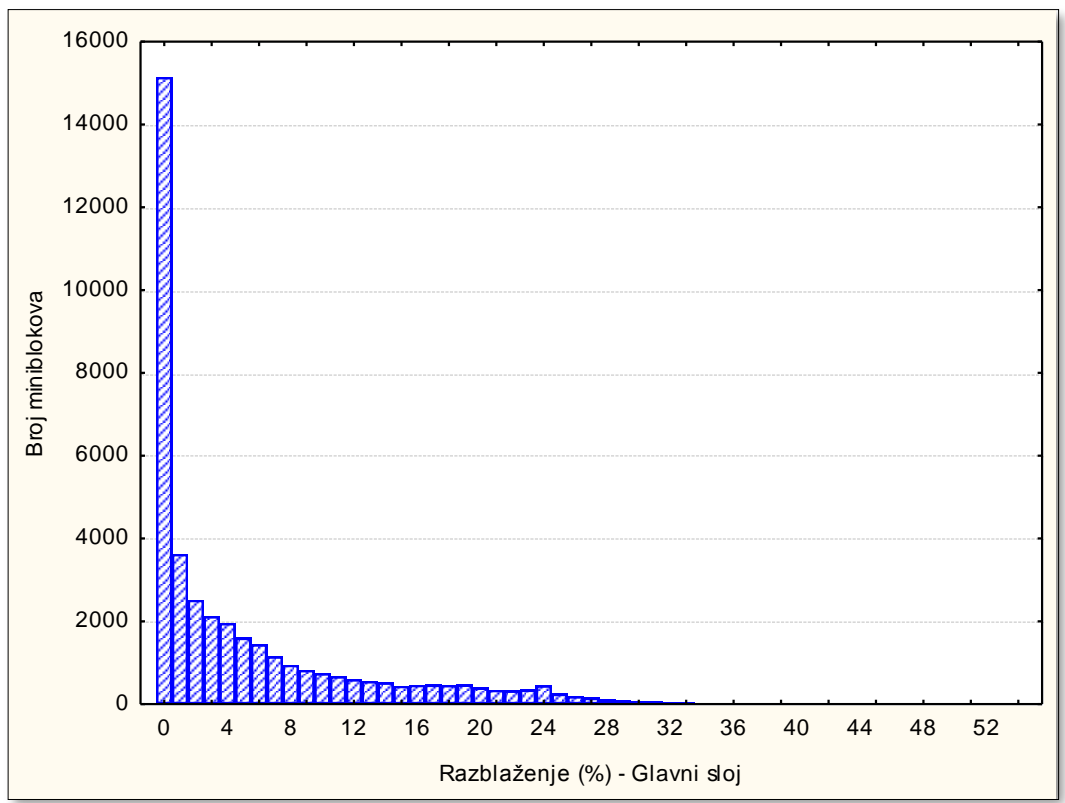

b)

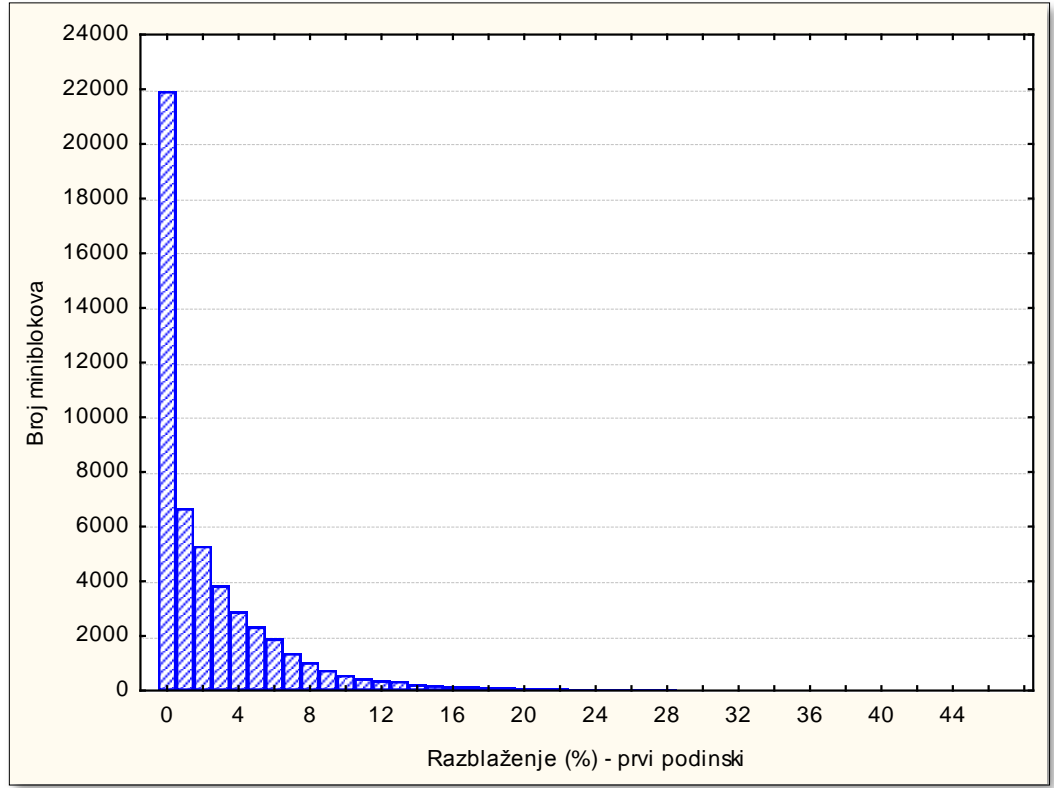

c) 


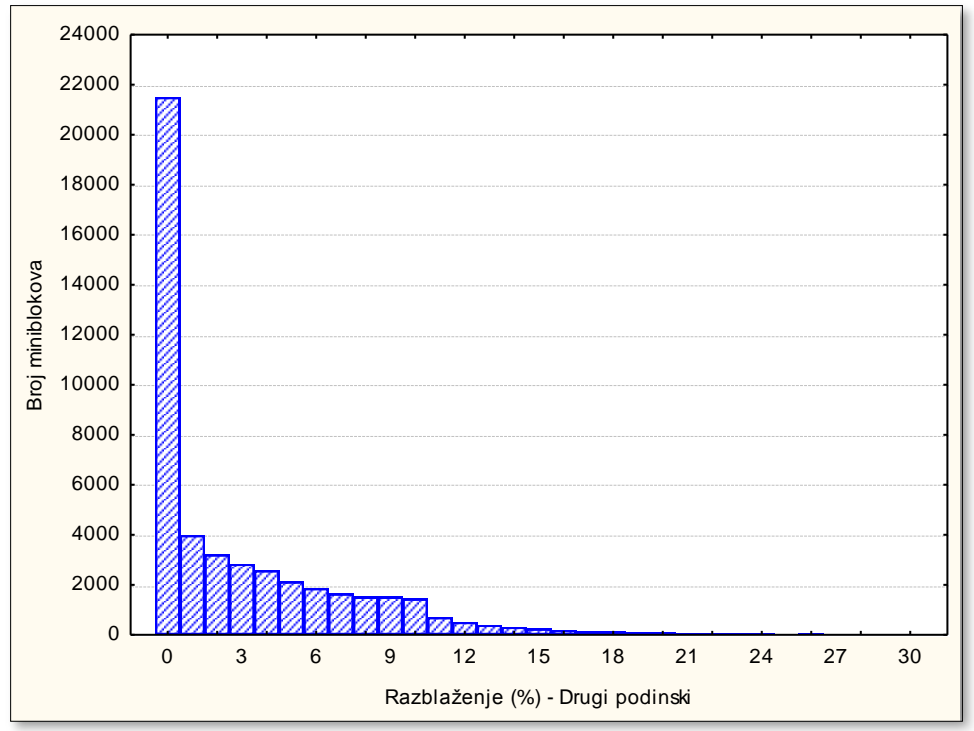

d)

Figure 11 Histograms of dilution percentage by coal seams

(a-roof, b-main, $c$-first floor and d-second floor coal seam) for the level selection of $1 \mathrm{~m}$

Table 2 Results of statistical analysis of dilution (\%) at the selection level of $0.5 \mathrm{~m}$

\begin{tabular}{|l|c|c|c|c|}
\hline \multicolumn{1}{|c|}{ Characteristic } & $\begin{array}{c}\text { Roof coal } \\
\text { seam }\end{array}$ & $\begin{array}{c}\text { Main coal } \\
\text { seam }\end{array}$ & $\begin{array}{c}\text { First floor } \\
\text { coal seam }\end{array}$ & $\begin{array}{c}\text { Second floor } \\
\text { coal seam }\end{array}$ \\
\hline Arithmetic mean & 2.604 & 5.701 & 3.057 & 3.441 \\
\hline Median & 0.172 & 2.375 & 1.541 & 1.505 \\
\hline Standard deviation & 4.556 & 7.535 & 4.457 & 4.470 \\
\hline Number of miniblocks & 12779 & 39661 & 51173 & 47227 \\
\hline Minimum & 0.000 & 0.000 & 0.000 & 0.000 \\
\hline Maximum & 36.773 & 54.046 & 47.826 & 30.393 \\
\hline I quartile & 0.000 & 0.094 & 0.011 & 0.000 \\
\hline II quartile & 3.286 & 8.185 & 4.208 & 5.616 \\
\hline
\end{tabular}

The quality of run-of mine coal is in a function of dilution degree, or waste percentage in run-of-mine coal. In order get to the mining coal quality, the following factors have to be taken into account leading to decrease in lower coal heating value, as follows:

- The effect of reducing the amount of clean coal in the total weight of runof-mine coal;
- The effect of increased amounts of moisture connected to the clayey and marl components in coal, and that is increased with participation the waste material in coal;

- Reducing the heating power of coal due to the presence of carbonate component that in the endothermic process decomposes to $\mathrm{CaO}$ and $\mathrm{CO}_{2}$. 
Table 3 shows the quality of coal by seams (the main coal seam, the first coal seam, the second coal and for the roof coal series) in the deposit as well as for the selection level of $0.5 \mathrm{~m}$ and $1 \mathrm{~m}$. The shown qualities are given as a function of analyzed and modeled dilution percenttage.

Table 3 Review the coal quality by seams in the deposit as well as for the selection level of $0.5 \mathrm{~m}$ and $1 \mathrm{~m}$

\begin{tabular}{|l|c|c|c|c|}
\hline & $\begin{array}{c}\text { Amounts } \\
(\mathbf{t})\end{array}$ & $\begin{array}{c}\text { DTE } \\
(\mathbf{k J} / \mathbf{k g})\end{array}$ & $\begin{array}{c}\text { DTE (kJ/kg) } \\
\text { for selection } \\
\text { level 0.5 m }\end{array}$ & $\begin{array}{c}\text { DTE (kJ/kg) } \\
\text { for selection } \\
\text { level 1 m }\end{array}$ \\
\hline Main coal seam & $29,945,042$ & 9,530 & 7,619 & 7,122 \\
\hline First floor coal seam & $9,788,561$ & 9,727 & 7,873 & 7,168 \\
\hline Second floor coal seam & $6,030,253$ & 9,555 & 7,403 & 7,289 \\
\hline $\begin{array}{l}\text { Main, first and second } \\
\text { floor seam }\end{array}$ & $\mathbf{4 5 , 7 6 3 , 8 5 6}$ & $\mathbf{9 , 5 7 5}$ & $\mathbf{7 , 6 4 5}$ & $\mathbf{7 , 1 5 4}$ \\
\hline Roof coal series & $20,144,899$ & 7,741 & 6,188 & 5,456 \\
\hline $\begin{array}{l}\text { Overall coal quality in case } \\
\text { of application the exclusive } \\
\text { selective exploitation }\end{array}$ & & & $\mathbf{7 , 1 9 9}$ & $\mathbf{6 , 6 3 5}$ \\
\hline
\end{tabular}

\section{CONCLUSION}

The present results of the analysis are a part of a broader study the possibilities of providing the appropriate coal quality for the needs of thermo power plant Gacko.

Having in mind the qualitative and structural characteristics of the coal deposit Centralno polje using only the selective exploitation, it was concluded that the production of minimum required coal quality cannot be expected. In order to achieve the required quality of fuel for the thermo power plant, it is necessary to apply a high selectivity during mining and restrict it to the parts of roof coal series with less pronounced stratification.

In spite of an expressed need for selective coal mining, in order to achieve the required quality of produced coal, the additional activities are required to improve the product quality. The additional improvement of coal quality is provided through a further process of processing - enrichment. Explanation the need and commitment to intro- duction the process of coal enrichment is given in the Strategy of Mining - Technological opening, develop-ment, optimization and maintenance a continuity of coal production with introduction the process of coal enrichment of dry separation at the open pit Gacko (Mining and Metallurgy Institute, Bor, 2015)

In case of application the selective coal mining, regardless whether the specific conditions re provided for further processing (enrichment) of coal, it is necessary to implement those procedures in the deposit analysis as a whole and certain parts by plan and at depth.

In this way, the parts of deposit can be identified with more complex mining conditions and lower quality of run-of-mine and to predict the expected coal quality. In this way, it is possible to plan development of mining works in a function of providing the required quality or to form a basis for the quality management system of coal. 


\section{REFERENCES}

[1] Strategy of Mining - Technological Opening, Development, Optimization and Maintenance a Continuity of Coal Production with Introduction the Process of Coal Enrichment of Dry Separation at the Open Pit - Gacko, Book 1, MMI Bor, Bor, 2015 (in Serbian)

[2] The Main Mining Project of the Open Pit Gacko - Central Field for Capacity of $2.3 \times 10^{6}$ t/year of Run-og-Mine coal, Project of the Open Pit Defense of Water, MMI Bor, Bor, 2016 (in Serbian)

[3] Simplified Mining Project of Exploitation a Part of the Field "C" with Expansion the Existing Work Front in the Southern Part and Part of Roof Coal ("Overlaying Zone") of the Open Pit "Gračanica" - Gacko, MMI Bor, Bor 2014 (in Serbian)

[4] V. Pavlović, D. Ignjatović: Selective Open Pit Coal Mining by Continuous Systems - University of Belgrade, Faculty of Mining and Geology (in Serbian)

[5] Lazić A., Bošković S., Klačar R.: Selective Open Pit Coal Mining, Monografija, University of Belgrade, Faculty of Mining and Geology (2004); (in Serbian) 